\title{
A CIDADE ANTIGA E A CIDADE ANTIGA CONTEMPORÂNEA
}

\author{
Gilberto da Silva Francisco ${ }^{1}$ \\ Glaydson José da Silva²
}

\begin{abstract}
“- Ah, impagável! Quer saber de outra? Tinha lido as cartas do Cônego Benigno, e resolveu ir logo ao sertão da Bahia, procurar a cidade misteriosa. Expôs-me o plano, descreveu-me a arquitetura provável da cidade, os templos, os palácios, gênero etrusco, os ritos, os vasos, as roupas, os costumes..."3
\end{abstract}

A cidade antiga depende da cidade contemporânea e a cidade contemporânea depende da cidade antiga. A nossa cidade é descrita, muito frequentemente, a partir de referências históricas nas quais a paisagem de cidades como Roma e de Atenas está fortemente presente. A cidade perdida no sertão baiano, no conjunto de referências do Cônego Benigno do "Anel de Polícrates" de Machado de Assis, é exatamente isso: uma cidade desconhecida, misteriosa; que, na criação discursiva, tem como base elementos da cidade mediterrânea antiga.

Ao mesmo tempo, as cidades antigas, tais como Roma e Atenas, são observadas e "reconstruídas" a partir de referências contemporâneas: Atenas, uma "cidademuseu" inspirada nas paisagens de exposições museológicas, como na obra La Cité des Images; ${ }^{4}$ ou Atenas transitando entre a noção de uma cidade central, um modelo trans-temporal, como proposto por George Grote; ${ }^{5}$ e a lógica de uma "cidade-exceção" no ambiente de desconstruções de firmes referências coloniais, como na obra de De Polignac, ${ }^{6}$ que assentou o terreno no qual o "atenocentrismo" criado por Grote foi sendo paulatinamente atenuado e criticado em consistentes projetos de observação mais ampla sobre a cidade antiga, que se tornava cada vez mais plural. ${ }^{7}$ Ou seja, quando mudamos, a cidade antiga também muda.

Outro exemplo disso é a atual inserção da lógica da cidade em paisagens mais amplas, conectadas e complexas que compõem uma perspectiva globalizada da cidade contemporânea. Assim, quando a cidade contemporânea se globalizou,

\footnotetext{
1 Professor Doutor - Universidade Federal de São Paulo, São Paulo, Brasil.

E-mail: gisifran@gmail.com

2 Professor Doutor - Universidade Federal de São Paulo, São Paulo, Brasil.

E-mail: sglaydson@hotmail.com

${ }^{3}$ MACHADO DE ASSIS, J. M. de, “O anel de Polícrates". In: Papéis avulsos. 1882.

${ }^{4}$ BÉRARD, C. et al. Le Cité des images : religion et société en Grèce antique. Paris: F. Nathann, 1984.

${ }^{5}$ A History of Greece; from the Earliest Period to the Close of the Generation Contemporary with Alexander the Great (12 vols.), 1846-1856.

${ }^{6}$ La naissance de la cité grecque. Cultes, espace et société, VIIIe-VIIe siècles avant J.-C. Paris: Éd. de la Découverte, 1984.

7 Ver, por exemplo, BROCK, R.; HODKINSON, S. Alternatives to Athens. Varieties of political organization and community in ancient Greece. Oxford: Oxford University Press, 2000 e HANSEN, M. H.; NIELSEN, Th. H. An inventory of Archaic and Classical poleis. Oxford: Oxford Univesity Press, 2006.
} 
ao mesmo tempo, a cidade antiga foi globalizada. E, além disso, os pontos de referência para a articulação do discurso sobre a cidade antiga também são fundamentais: a cidade de Fustel de Coulanges baseada na religião; ${ }^{8}$ a cidade de Gordon Childe observada a partir dos modos de produção no seio da "Revolução Urbana"; 9 a cidade de Max Weber, na qual o elemento central é o homo politicus, por oposição ao homo economicus da cidade medieval;10 entre outras.

Dessa forma, considerando a grande importância de entender essas duas "cidades" (a antiga e a contemporânea) em paralelo, e mesmo a sua codependência, é imperativo refletir sobre a cidade antiga a partir de seus vestígios, mas também a partir de seus interpretadores e a dinâmica de tendências que a colocam no centro do debate sobre o mundo clássico na Antiguidade e suas complexas conexões com o "mundo ao redor". É nesse ambiente que conceitos importantes aparecem para descrever a organização dessas cidades: pólis, política, cidade-estado, mercado, redes, paisagens, conexões, identidades etc.

É nesse intuito que a Revista Heródoto apresenta o dossiê "Cidades e periferias no mundo Antigo"; contribuindo com mais um modesto tijolo na construção de um cenário amplo e crítico sobre a cidade antiga a partir dos aspectos discursivos e materiais que a compuseram, e continuam a compor, os debates que denunciam a sua complexidade. Assim, acreditamos que, enquanto o debate sobre ela existir, a cidade antiga continua viva, ativa e uma referência fundamental para se pensar a cidade que vivemos.

As contribuições do dossiê "Cidades e Periferias no Mundo Antigo" abordam várias das questões acima colocadas em profundidade, assim como a entrevista muito gentilmente concedida à nossa revista pela Professora Maria Beatriz Borba Florenzano (Museu de Arqueologia e Etnologia da Universidade de São Paulo, MAE-USP); que também colaborou com a organização deste dossiê. Assim, agradecemos muitíssimo à Professora Florenzano pelo apoio, bem como aos que contribuíram para este número da Revista Heródoto.

Desejamos uma excelente leitura a todos.

\footnotetext{
8 FUSTEL DE COULANGES, N.-D. A Cidade Antiga. São Paulo: Ed. das Américas, 2006.

${ }^{9}$ CHILDE, V. G. O que aconteceu na História. Rio de Janeiro: Zahar, 1977.

10 WEBER, M. Economia e Sociedade. São Paulo: Ed. UNB, 2004.
} 